\title{
High parity and hormonal contraception use as risk factors for cervical cancer in East Kalimantan
}

\author{
Swandari Paramita, ${ }^{1}$ Soetomo Soewarto, ${ }^{2}$ M. Aris Widodo, ${ }^{3}$ Sutiman B. Sumitro ${ }^{4}$ \\ ${ }^{1}$ Laboratory of Public Health, Faculty of Medicine, Universitas Mulawarman, Samarinda, Indonesia \\ ${ }^{2}$ Department of Obstetrics and Gynecology, Faculty of Medicine, Universitas Brawijaya, Malang, Indonesia \\ ${ }^{3}$ Laboratory of Pharmacology, Faculty of Medicine, Universitas Brawijaya, Malang, Indonesia \\ ${ }^{4}$ Department of Biology, Faculty of Mathematics and Natural Sciences, Universitas Brawijaya, Malang, Indonesia
}

\begin{abstract}
Abstrak
Tujuan: Mengetahui faktor-faktor risiko yang berhubungan dengan terjadinya kanker serviks.

Metode: Penelitian kasus-kontrol ini dilakukan di RSUD A.W. Sjahranie Samarinda Kalimantan Timur mulai Januari hingga Juli 2009. Bilangan masing-masing 58 pasien untuk setiap kelompok kasus dan kontrol. Variabel dalam penelitian ini adalah usia, menarche, menopause, usia pertama kali menikah, paritas, status merokok suami, penggunaan kontrasepsi hormonal, jenis kontrasepsi hormonal, lama kontrasepsi hormonal, penggunaan kontrasepsi IUD (intra uterine device) dan lama kontrasepsi IUD.
\end{abstract}

Hasil: Analisis data final menunjukkan bahwa paritas dan lama penggunaan kontrasepsi hormonal meningkatkan risiko kanker serviks. Perempuan dengan 5-12 anak dibandingkan 0-4 anak memiliki peningkatan risiko kanker serviks sebanyak 2,6 kali. Jika dibandingkan dengan perempuan yang tidak menggunakan kontrasepsi hormonal, mereka yang menggunakan selama 1-4 tahun dan 5-25 tahun memiliki peningkatan risiko kanker serviks sebanyak 2 dan 4,5 kali.

Kesimpulan: Skrining terhadap kanker serviks disarankan lebih difokuskan pada perempuan berisiko tinggi, khususnya perempuan yang pernah melahirkan anak lebih dari 5 kali atau perempuan yang menggunakan kontrasepsi hormonal dengan lama pemakaian lebih dari 5 tahun. (Med J Indones 2010; 19:268-72)

\begin{abstract}
Aim: To find risk factors associated with cervical cancer.

Methods: This a case-control study conducted in A.W. Sjahranie County General Hospital at Samarinda East Kalimantan from January until July 2009. There were 58 patients for each case and control group. Variables in this study were age, menarche, menopause, age of first marriage, parity, spouse's smoking status, hormonal contraception use, type of hormonal contraception, duration of hormonal contraception, IUD (intra uterine device) contraception use and duration of IUD contraception.

Results: final data analysis shows that parity and duration of hormonal contraception use increased the risk of cervical cancer. Women who had 5-12 children than 0-4 children had 2.6-folds increased risk to be cervical cancer. Compared to women never use of hormonal contraception, those who ever had hormonal contraception for 1-4 years and 5-25 years had two time and 4.5 times increased risk to be cervical cancer respectively.

Conclusion: Cervical cancer screening recommended to be focused on high-risk groups, among others, women with the number of children born more than five people or women in particular users of hormonal contraception methods with a range of use more than five years. (Med J Indones 2010; 19:268-72)
\end{abstract}

Key words: Cervical cancer, hormonal contraception, menarche, parity

Cervical cancer is the second biggest cause of female cancer mortality worldwide with 288,000 deaths yearly. About 510,000 cases of cervical cancer are reported each year with nearly $80 \%$ in developing countries: 68,000 in Africa, 77,000 in Latin America, and 245,000 in Asia. ${ }^{1}$

Cervical cancer ranks as the 3rd most frequent cancer among women in Indonesia, and the 2nd most frequent Correspondence email to: swandariparamita@yahoo.com cancer among women between 15 and 44 years of age. Indonesia has a population of 79.14 million women ages 15 years and older who are at risk of developing cervical cancer. Current estimates indicate that every year more than 13,500 women are diagnosed with cervical cancer and almost 7,500 die from the disease. ${ }^{2}$

It is now well established that HPV(humanpapillomavirus) infection is the necessary cause of cervical cancer and its 
immediate precursor cervical intraepithelial neoplasia. However, HPV infection alone may not be sufficient to cause cervical cancer, and other factors might exist that, in conjunction with HPV, influence the risk of progression from cervical HPV infection to cervical cancer. Based on key studies on cervical intraepithelial neoplasia and cervical cancer conducted among HPVpositive women, it can be concluded that high parity and long-term hormonal contraceptives use are cofactors that may modulate the risk of progression from HPV infection to cervical intraepithelial neoplasia and cervical cancer. ${ }^{3}$

Hormonal changes induced by pregnancy (increased levels of estrogen and progesterone) and hormonal contraceptives use may modulate the immune response to HPV and influence risk of persistence or progression. Hormonal mechanisms have been hypothesized as biologically plausible explanations for the association between parity and cervical intraepithelial neoplasia or cervical cancer among infected women; however, because of the concordance of effects with hormonal contraceptives use, hormonal influences can be considered one of the most promising candidates in the search for HPV cofactors.4,5 Based on that, the study conducted to analyze the risk factors of cervical cancer in women.

\section{METHODS}

This case-control study conducted on women in East Kalimantan. Case was subject who had cervical cancer and cervical intraepithelial neoplasia diagnosed at the A.W. Sjahranie County General Hospital of the Faculty of Medicine Universitas Mulawarman in Samarinda, East Kalimantan was recruited. Histopathological examination determined of patients for case or control groups. All cases and controls were eligible for the study if they met the following criteria (more than 17 years of age or has been married and agreed to participate in this study).

Cases were obtained sequentially during the period from January 2009 through June 2009 and represent all the patients with newly diagnosed cervical cancer in this period.

Controls were those who underwent cervical or surgical biopsy for histopathologically examination with normal result diagnosed at the A.W. Sjahranie County General Hospital during the same period as cases.

Fifty eight control subjects were selected from Colposcopically and surgically biopsy specimens were obtained from the case and control patients. Tissues were fixed in formalin, embedded in paraffin, and stained with hematoxylin-eosin for routine pathologic diagnosis. All diagnoses were biopsy confirmed by hospital pathologists at the time of initial diagnosis.

Researcher conducted interviews to collect information on demographics, reproductive history and contraceptive use from the patients. The interviews were conducted in hospital along with patients receive their biopsy results. Variables in this study were age, menarche, menopause, age of first marriage, parity, spouse's smoking status, hormonal contraception use, type of hormonal contraception, duration of hormonal contraception, IUD (intra uterine device) contraception use and duration of IUD contraception. The relative risk of cancer was estimated by calculating Odds Ratio (OR) using logistic regression. All analyses were done using SPSS 11.5.

Informed written consent was obtained from all participants, and the study protocol was approved by the Research Ethics Commission on Faculty of Medicine of Universitas Brawijaya.

\section{RESULTS}

Among the 58 subjects, $27.5 \%$ were cervical intraepithelial neoplasia, 48,3\% were squamous cell carcinomas, $13.8 \%$ were adenocarcinomas, $6.9 \%$ were adenosquamous carcinomas, and 3.4\% were small cell carcinomas.

Table 1. Several demographics, gynecologic characteristics and risk of cervical cancer

\begin{tabular}{|c|c|c|c|c|c|c|c|}
\hline & \multicolumn{4}{|c|}{ Cervical cancer } & \multirow{3}{*}{$\begin{array}{l}\text { Crude } \\
\text { odds } \\
\text { ratio }\end{array}$} & \multirow{3}{*}{$\begin{array}{c}95 \% \\
\text { confidence } \\
\text { interval }\end{array}$} & \multirow[t]{3}{*}{$\mathrm{P}$} \\
\hline & \multicolumn{2}{|c|}{$\begin{array}{l}\text { Control } \\
(n=58)\end{array}$} & \multicolumn{2}{|c|}{$\begin{array}{c}\text { Case } \\
(n=58)\end{array}$} & & & \\
\hline & $\mathrm{n}$ & $\%$ & $\mathrm{n}$ & $\%$ & & & \\
\hline \multicolumn{8}{|l|}{ Age } \\
\hline 23-50 years & 48 & 82.8 & 47 & 81.0 & 1.00 & Reference & \\
\hline 51-67 years & 10 & 17.2 & 11 & 19.0 & 1.12 & $0.44-2.89$ & 0.809 \\
\hline \multicolumn{8}{|l|}{ Menarche } \\
\hline 11-12 years & 9 & 15.5 & 17 & 29.3 & 1.00 & Reference & \\
\hline 13-19 years & 49 & 84.5 & 41 & 70.7 & 0.44 & 0.18-1.01 & 0.079 \\
\hline \multicolumn{8}{|l|}{ Menopause } \\
\hline No & 53 & 91.4 & 46 & 79.3 & 1.00 & Reference & \\
\hline Yes & 5 & 8.6 & 12 & 20.7 & 2.77 & $0.91-0.437$ & 0.074 \\
\hline \multicolumn{8}{|c|}{$\begin{array}{l}\text { Age on first time } \\
\text { married }\end{array}$} \\
\hline 12-16 years & 17 & 29.3 & 10 & 17.2 & 1.00 & Reference & \\
\hline $17-30$ years & 41 & 70.7 & 48 & 82.8 & 2.00 & $0.82-4.82$ & 0.128 \\
\hline \multicolumn{8}{|l|}{ Parity } \\
\hline 0-4 children & 50 & 86.2 & 41 & 70.7 & 1.00 & Reference & \\
\hline 5-12 children & 8 & 13.8 & 17 & 29.3 & 2.59 & $1.02-6.61$ & 0.046 \\
\hline \multicolumn{8}{|c|}{$\begin{array}{l}\text { Spouse's smoking } \\
\text { status }\end{array}$} \\
\hline Never & 22 & 37.9 & 15 & 25.9 & 1.00 & Reference & \\
\hline Ever & 36 & 62.1 & 43 & 74.1 & 1.75 & $0.79-3.87$ & 0.165 \\
\hline
\end{tabular}


Table 1 show that women with case of cervical cancer and healthy control were equally distributed in terms of age group. Compared to the respective references, those who were menopause, age first time married in 17-30 years, parity of 5-12 children, and her spouse ever had smoking more likely had cervical cancer. However, those who had menarche 13-19 years less likely had cervical cancer.

Table 2. Several contraception used and risk of cervical cancer

\begin{tabular}{|c|c|c|c|c|c|c|c|}
\hline & \multicolumn{4}{|c|}{ Cervical cancer } & \multirow{3}{*}{$\begin{array}{l}\text { Crude } \\
\text { odds } \\
\text { ratio }\end{array}$} & \multirow{3}{*}{$\begin{array}{c}95 \% \\
\text { confidence } \\
\text { interval }\end{array}$} & \multirow{3}{*}{$\mathrm{P}$} \\
\hline & \multicolumn{2}{|c|}{$\begin{array}{l}\text { Control } \\
(\mathrm{n}=58)\end{array}$} & \multicolumn{2}{|c|}{$\begin{array}{l}\text { Case } \\
(\mathrm{n}=58)\end{array}$} & & & \\
\hline & $n$ & $\%$ & $\mathrm{n}$ & $\%$ & & & \\
\hline \multicolumn{8}{|l|}{$\begin{array}{l}\text { Hormonal } \\
\text { contraception }\end{array}$} \\
\hline Never & 28 & 48.3 & 14 & 24.1 & 1.00 & Reference & \\
\hline Ever & 30 & 51.7 & 44 & 75.9 & 2.93 & $1.33-6.48$ & 0.007 \\
\hline \multicolumn{8}{|l|}{$\begin{array}{l}\text { Type of } \\
\text { hormonal } \\
\text { contraception }\end{array}$} \\
\hline Never & 28 & 48.3 & 14 & 24.1 & 1.00 & Reference & \\
\hline $\begin{array}{l}\text { Estrogen and } \\
\text { progestin }\end{array}$ & 19 & 32.8 & 40 & 69.0 & 4.21 & $1.81-9.78$ & 0.001 \\
\hline Progestin only & 11 & 19.0 & 4 & 6.9 & 0.73 & $0.20-2.70$ & 0.753 \\
\hline \multicolumn{8}{|l|}{$\begin{array}{l}\text { Duration of } \\
\text { hormonal } \\
\text { contraception }\end{array}$} \\
\hline None & 28 & 48.3 & 14 & 24.1 & 1.00 & Reference & \\
\hline 1-4 years & 12 & 20.7 & 15 & 25.9 & 2.11 & $0.85-5.24$ & 0.107 \\
\hline 5-25 years & 18 & 31.0 & 29 & 50.0 & 4.17 & $1.62-10.67$ & 0.003 \\
\hline \multicolumn{8}{|l|}{$\begin{array}{l}\text { IUD } \\
\text { contraception }\end{array}$} \\
\hline Never & 41 & 70.7 & 39 & 67.2 & 1.00 & Reference & \\
\hline Ever & 17 & 29.3 & 19 & 32.8 & 1.18 & $0.54-2.58$ & 0.688 \\
\hline \multicolumn{8}{|l|}{$\begin{array}{l}\text { Duration of IUD } \\
\text { contraception }\end{array}$} \\
\hline None & 41 & 70.7 & 39 & 67.2 & 1.00 & Reference & \\
\hline 1-4 years & 7 & 12.1 & 6 & 10.3 & 9.24 & $0.28-2.93$ & 0.862 \\
\hline 5-25 years & 10 & 17.2 & 13 & 22.4 & 1.37 & $0.54-3.48$ & 0.512 \\
\hline
\end{tabular}

Table 2 shows that women with case of cervical cancer and healthy control were equally distributed in terms of IUD contraception, and who ever had progestin only hormonal contraconception. Compared to the respective references, women who ever used hormonal contraception with estrogen and progestin, and had any hormonal contraconception were more likely risk had cervical cancer.
Table 3. Relationship among Menarche, parity, duration of hormonal contraception and risk of cervical cancer

\begin{tabular}{|c|c|c|c|c|c|c|c|}
\hline & \multicolumn{4}{|c|}{ Cervical cancer } & \multirow{3}{*}{$\begin{array}{l}\text { Adjusted } \\
\text { odds } \\
\text { ratio* }\end{array}$} & \multirow{3}{*}{$\begin{array}{c}95 \% \\
\text { Confidence } \\
\text { Interval }\end{array}$} & \multirow{3}{*}{$\mathrm{P}$} \\
\hline & \multicolumn{2}{|c|}{$\begin{array}{l}\text { Control } \\
(n=58)\end{array}$} & \multicolumn{2}{|c|}{$\begin{array}{l}\text { Case } \\
(\mathrm{n}=58)\end{array}$} & & & \\
\hline & $\mathrm{n}$ & $\%$ & $\mathrm{n}$ & $\%$ & & & \\
\hline \multicolumn{8}{|l|}{ Menarche } \\
\hline 11-12 years & 9 & 15.5 & 17 & 29.3 & 1.00 & Reference & \\
\hline 13-19 years & 49 & 84.5 & 41 & 70.7 & 0.39 & $0.14-1.09$ & 0.074 \\
\hline \multicolumn{8}{|l|}{ Parity } \\
\hline 0-4 children & 50 & 86.2 & 41 & 70.7 & 1.00 & Reference & \\
\hline 5-12 children & 8 & 13.8 & 17 & 29.3 & 2.62 & $0.91-7.55$ & 0.073 \\
\hline \multicolumn{8}{|l|}{$\begin{array}{l}\text { Duration of } \\
\text { hormonal } \\
\text { contraception }\end{array}$} \\
\hline None & 28 & 48.3 & 14 & 24.1 & 1.00 & Reference & \\
\hline 1-4 years & 12 & 20.7 & 15 & 25.9 & 2.06 & $0.84-5.34$ & 0.113 \\
\hline 5-25 years & 18 & 31.0 & 29 & 50.0 & 4.48 & $1.73-11.56$ & 0.002 \\
\hline
\end{tabular}

Our final model (Table 3) reveals parity and duration of hormonal contraception use increased the risk of cervical cancer. Women who had menarche aged 13-19 years than $11-12$ years had less $61 \%$ less to be cervical cancer. In term of parity, those who had 5-12 children than 0 -4 children had 2.6-folds to be cervical cancer. Women who had longer time of hormonal contraception had increase risk to be cervical cancer. Compared to women never use of hormonal contraception, those who ever had hormonal contraception for 1-4 years and 5-25 years had two time and 4.5 times increased risk to be cervical cancer respectively.

\section{DISCUSSION}

The results of this study indicate that parity and hormonal contraception use are risk factors for cervical cancer. Our study results have similar results with pooled-analysis study by Castellsagué et al. for the International Agency for Research on Cancer Multicenter Cervical Cancer Study Group, which found cofactors that showed statistically significant associations with cervical carcinoma including longterm use of hormonal contraception and high parity. ${ }^{6}$

The study by Hildesheim et al. in Costa Rica found that risk of precancerous lesions and cervical cancer increased with increasing number of live births. This study also found that oral contraception use was associated with precancerous lesions and cervical 
cancer. In this study, both factors of high parity and oral contraception use, increase the risk of precancerous lesions and cervical cancer in women with positive HPV infection. ${ }^{7}$

In addition, a study by Thomas et al. in Thailand also found that the risk of cervical cancer increased with parity and use of oral contraceptives but not with injectable progestogen. The study also found that factors that may predispose to persistent oncogenic HPV-16 or -18 infections might include estrogens or progestins in the presence of estrogens. ${ }^{8}$

In term of risk factor of high parity, study by Muñoz et al. for International Agency for Research on Cancer, Multicentric Cervical Cancer Study Group showed that high parity increases the risk of squamous-cell carcinoma of the cervix among HPV-positive women. They found a direct association between the number of full-term pregnancies and squamous-cell cancer risk: the odds ratio for seven full-term pregnancies or more was $3.8(95 \% \mathrm{CI}=2.7-5.5)$ compared with nulliparous women, and 2.3 (95\% CI=1.6-3.2) compared with women who had one or two full-term pregnancies. ${ }^{5}$ Study by Bayo et al. in Mali showed that risk factors for cervical cancer were parity $>10$ versus $<5$ children $(\mathrm{OR}=4.8,95 \% \mathrm{CI}=1.5-14.7) .^{9}$

Kjellberg et al study in Sweden showed that pregnancy appeared to be a risk factor of cervical cancer in the multivariate analysis $(\mathrm{P}<0.001) .{ }^{10}$ Meanwhile, study by De Boer et al. in Indonesia also showed that high parity were significant risk factors for cervical cancer. ${ }^{11}$

In term of risk factor of hormonal contraception use, study by Moreno et al. for International Agency for Research on Cancer, Multicentric Cervical Cancer Study Group, showed that long-term use of oral contraceptives could be a cofactor that increases risk of cervical carcinoma by up to four-fold in women who are positive for cervical HPV DNA. The odds ratio for use of oral contraceptives was 2.82 (95\% CI=1.465.42) for 5-9 years, and 4.03 (95\% CI=2.09-8.02) for use for 10 years or longer, and these risks did not vary by time since first or last use. ${ }^{4}$

Meanwhile study by International Collaboration of Epidemiological Studies of Cervical Cancer among current users of oral contraceptives the risk of invasive cervical cancer increased with increasing duration of use [relative risk for 5 or more years' use versus never use was 1.90 (95\% CI=1.69-2.13)]. 10 years' use of oral contraceptives from around age 20 to 30 years is estimated to increase the cumulative incidence of invasive cervical cancer by age 50 from 7.3 to 8.3 per 1000 in less developed countries and from 3.8 to 4.5 per 1000 in more developed countries. ${ }^{12}$

Study by Madeleine et al. in U.S. showed that the relative risk of cervical cancer increased with duration of oral contraceptives use, with the highest risk for 12 or more years of use $(\mathrm{OR}=5.5 ; 95 \% \mathrm{CI}=2.1-14.6)$ relative to nonusers. ${ }^{13}$ Meanwhile, study by Vanankovit and Taneepanichskul in Thailand also showed that long-term use of oral contraceptive might be a cofactor that increases the risk of cervical carcinoma, the odds ratio of oral contraceptive pill use for more than 3 years was 2.57 (95\% CI $=1.22-5.49)$ which was statistically significant. ${ }^{14}$

In conclusion, parity 5 times or more and longer duration of hormonal contraception use 5 years or more increased risk cervical cancer in East Kalimantan. Therefore, cervical cancer screening recommended to be focused on high-risk groups, among others, women with the number of children born more than five people or women in particular users of hormonal contraception methods with a range of use more than five years.

\section{REFERENCES}

1. World Health Organization. World: Human Papillomavirus and Related Cancer, Summary Report Update 2010. Geneva: World Health Organization. 2010;8-14.

2. World Health Organization. Indonesia:Human Papillomavirus and Related Cancer, Summary Report Update 2010. Geneva: World Health Organization. 2010;6-11.

3. Castellsagué X, Muñoz N. Chapter 3: Cofactors in human papillomavirus carcinogenesis- role of parity, oral contraceptives, and tobacco smoking. JNCI Monographs. 2003;31: 20-8.

4. Moreno V, Bosch FX, Muñoz N, Meijer CJ, Shah KV, Walboomers JM, et al. International agency for research on cancer, multicentric cervical cancer study group. Effect of oral contraceptives on risk of cervical cancer in women with human papillomavirus infection: The IARC Multicentric Case-Control Study. Lancet. 2002;359:1085-92.

5. Muñoz N, Franceschi S, Bosetti C, Moreno V, Herrero R, Smith JS, et al. International agency for research on cancer, multicentric cervical cancer study group. Role of parity and human papillomavirus in cervical cancer: The IARC Multicentric CaseControl Study. Lancet. 2002; 359:1093-101.

6. Castellsagué X, Díaz M, de Sanjosé S, Muñoz N, Herrero $\mathrm{R}$, Franceschi S, et al. Worldwide human papillomavirus etiology of cervical adenocarcinoma and its cofactors: implications for screening and prevention. JNCI. 2006;98:303-15.

7. Hildesheim A, Herrero R, Castle PE, Wacholder S, Bratti MC, Sherman ME et al. HPV co-factors related to the 
development of cervical cancer: results from a populationbased study in Costa Rica. Br J Cancer. 2001; 84: 1219-26.

8. Thomas DB, Ray RM, Koetsawang A, Kiviat N, Kuypers J, Qin Q, et al. Human papillomaviruses and cervical cancer in Bangkok. I. Risk factors for invasive cervical carcinomas with human papillomavirus types 16 and 18 DNA. Am J Epidemiol. 2001;153:723-31.

9. Bayo S, Bosch FX, de Sanjosé S, Muñoz N, Combita AL, Coursaget $\mathrm{P}$, et al. Risk factors of invasive cervical cancer in Mali. Int J Epidemiol. 2002; 31: 202-9.

10. Kjellberg L, Hallmans G, Ahren AM, Johansson R, Bergman F, Wadell G, et al. Smoking, diet, pregnancy and oral contraceptive use as risk factors for cervical intra-epithelial neoplasia in relation to human papillomavirus infection. $\mathrm{Br}$ J Cancer. 2000;82:1332-8.

11. De Boer MA, Vet JN, Aziz MF, Cornain S, Purwoto G, van den Akker BE, et al. Human papillomavirus type 18 and other risk factors for cervical cancer in Jakarta, Indonesia. Int J Gynecol Cancer. 2006;16:1809-14.

12. International Collaboration of Epidemiological Studies of Cervical Cancer, Appleby P, Beral V, Berrington de González A, Colin D, Franceschi S, et al. Cervical cancer and hormonal contraceptives: Collaborative reanalysis of individual data for 16,573 women with cervical cancer and 35,509 women without cervical cancer from 24 epidemiological studies. Lancet. 2007;370: 1609-21.

13. Madeleine MM, Daling JR, Schwartz SM, Shera K, McKnight B, Carter JJ, et al. Human papillomavirus and long-term oral contraceptive use increase the risk of adenocarcinoma in situ of the cervix. Cancer Epidemiol Biomarkers Prev. 2001;10:171-7.

14. Vanakankovit N, Taneepanichskul S. Effect of oral contraceptives on risk of cervical cancer. J Med Assoc Thai. 2008;91:7-12. 